Ching-Tien Peng • Jer-Yuarn Wu • Chang-Hai Tsai

Fuu-Jen Tsai • Jan-Gowth Chang

\title{
Molecular diagnosis of patients with $\beta$-thalassemia major in central Taiwan by amplified created restriction site analysis
}

\begin{abstract}
Thalassemia, a hematologic disorder characterized by the deficiency or the absence of $\beta$-globin production, is the most widespread inherited disorder in the world; it is also common in Taiwan. We studied 38 patients in central Taiwan with $\beta$-thalassemia major, using amplified created restriction site analysis for detection. On analysis, six different point mutations were found among 76 chromosomes, of which 32 chromosomes $(42.1 \%)$ had a $\mathrm{C}$ to $\mathrm{T}$ substitution at nucleotide $654,30(40 \%)$ had frameshift codons 41/42 with four nucleotides (TCTT) deletion, 7 (9.2\%) had an A to T substitution at codon 17,3 (3.9\%) had frameshift codons 71/72 (insertion of A), $2(2.6 \%$ ) had an A to $\mathrm{G}$ substitution at position -28 , and $2(2.6 \%)$ had frameshift codons 27/28 (insertion of C). The first two mutations accounted for 62 of the $76 \beta$-thalassemia mutations in this study. As to mutations in each individual with $\beta$-thalassemia major, the incidence of compound heterozygotes of two different mutations was higher than that of homozygotes of a single mutation ( $60 \%$ vs $40 \%)$. Compound heterozygotes of $\mathrm{C}$ to $\mathrm{T}$ substitution at nucleotide 654 of IVS-2 and frameshift codons $41 / 42$ with four-nucleotide deletion was the most common pattern of $\beta$-thalassemia mutations in each individual $(23.7 \%)$. Our results were unique compared with those from similar studies performed in southern China. Frequencies of $\beta$-thalassemia mutations found in the current study were assessed and compared with frequencies found in previous studies conducted in northern and southern Taiwan.
\end{abstract}

Key words $\beta$-Thalassemia $\cdot$ Mutation screening $\cdot$ Amplified created restriction site (ACRS) - Taiwanese.

C.-T. Peng $(\triangle) \cdot$ C.-H. Tsai $\cdot$ F.-J. Tsai

Department of Pediatrics, China Medical College Hospital, 2

Yuh-Der Road, Taichung, Taiwan

Tel. +886-4-2052121 ext. 2409; Fax + 886-4-2032798

e-mail: penect@hpd.cmch.org.tw

J.-Y. Wu $\cdot$ J.-G. Chang

Department of Medical Research, China Medical College Hospital,

Taichung, Taiwan

\section{Introduction}

$\beta$-Thalassemia is common in peoples of the Mediterranean region, Middle East, Southeast Asia, and southern China (Weatherall et al. 1981). Worldwide, 216 known mutations are currently documented in the $\beta$-globin gene. The disease is common in Taiwan, which is located about 100 miles off the southeast coast of mainland China, and has a population of about 21 million. The people of Taiwan consist of four main ethnic populations: Min-Nan $(12,521,000)$, Hakka $(5,411,000)$, Mainlander $(3,229,000)$, and Aborigine $(369,000)$. The carrier frequency of $\beta$-thalassemia is estimated to be between $1 \%$ and $3 \%$ (Ko et al. 1989). The mutations of $\beta$-thalassemia in northern and southern Taiwan have been extensively studied by Xu et al. (1990), Lin et al. (1991, 1992), Chang et al. (1992), and Chiou et al. (1993). We reviewed and analyzed the eight most common mutations for this study, whose purpose was to determine the different mutations of the $\beta$-globin gene in 38 patients with $\beta$-thalassemia major and to review the patients' different clinical characteristics. Results were assessed and compared with those from similar studies in order to better understand those mutation characteristics that could be useful in genetic counseling and prenatal diagnosis programs for $\beta$-thalassemia patients in Taiwan. These patients were first diagnosed using hemoglobin analysis. Mutations of the $\beta$-globin gene were detected by amplified created restriction site (ACRS) analysis.

\section{Subjects and methods}

Subjects

A total of 38 patients with $\beta$-thalassemia major from China Medical College Hospital were studied. All patients (age, $2-$ 25 years) came from the central Taiwan area (Fig. 1) and were diagnosed by hemoglobin electrophoresis. The birthplaces and ethnic backgrounds of all 76 parents were recorded (Min-Nan, 52; Hakka, 19; Mainlander, 5). All 
patients required regular transfusions to maintain a hemoglobin level greater than $8 \mathrm{~g} / \mathrm{dl}$. Brief clinical data, including day of initial transfusion, hemoglobin $(\mathrm{Hb})$ value, $\mathrm{HbF}$, $\mathrm{HbA}_{1}$, and $\mathrm{HbA}_{2}$ were measured for each patient.

\section{ACRS analysis of $\beta$-thalassemia}

The genomic DNA was extracted from the buffy coat cells of $8-10 \mathrm{ml}$ of heparinized peripheral blood of the patients and their parents with a DNA Extractor WB Kit (Wako, Tokyo, Japan). $\beta$-Thalassemia mutations were directly detected by the method of naturally and amplified created restriction sites, as previously described (Chang et al. 1992). Table 1 shows the sequences of primers, the natural or created enzyme restriction sites, and the resulting fragment sizes after digestion.

Amplification conditions were as follows. Briefly, $0.1 \mu \mathrm{g}$ of genomic DNA was mixed with $100 \mathrm{ng}$ of each primer and $200 \mu \mathrm{m}$ of each dNTP in $100 \mu \mathrm{l}$ reaction buffer containing $10 \mathrm{mM}$ Tris- $\mathrm{HCl}$ ( $\mathrm{pH} 8.3$ ), $50 \mathrm{mM} \mathrm{KCl}, 15 \mathrm{mM} \mathrm{MgCl}_{2}$, and $0.01 \%$ gelatin. The mixture was incubated at $94^{\circ} \mathrm{C}$ for $2 \mathrm{~min}$ for strand separation and then 5 units of Taq polymerase

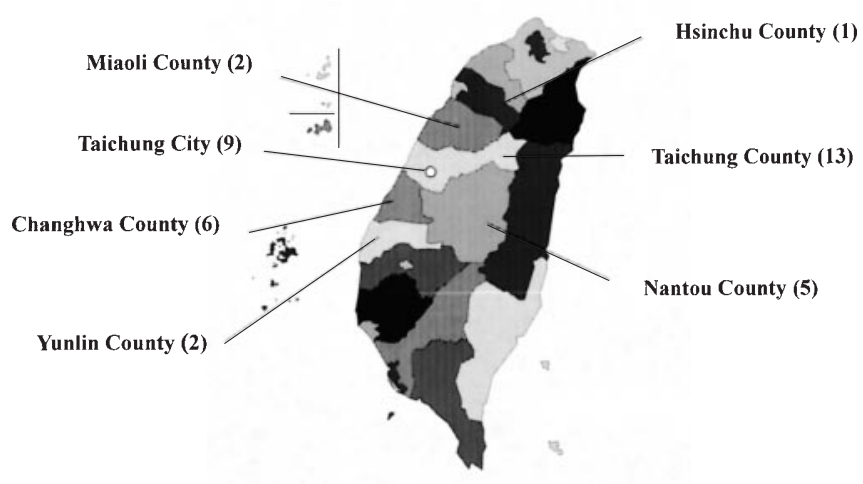

Fig. 1 Distribution of 38 patients with $\beta$-thalassemia major in central Taiwan. Figures in parentheses indicate numbers of patients were added. Thirty-five cycles of denaturation at $94^{\circ} \mathrm{C}$ for $2 \mathrm{~min}$, annealing at $55^{\circ} \mathrm{C}$ for $2 \mathrm{~min}$, and extension at $72^{\circ} \mathrm{C}$ for 3 min were performed by a Perkin-Elmer DNA Thermal Cycler (Foster City, CA, USA) (Wong et al. 1987).

\section{Results}

Detection of mutation by ACRS

Table 2 shows the results of $\beta$-thalassemia mutation detection in different ethnic groups in central Taiwan and a comparison of the relative frequencies of nine common mutations in different areas of Taiwan. Six of the nine mutations were found in our 38 study patients. The pattern of mutations showed a similar trend based on the three major ethnic groups in central Taiwan (Min-Nan, Hakka, and Mainlanders), but no Aborigines were among the current study population. All patients with $\beta$-thalassemia major were found to have mutations in both $\beta$-globin alleles, either homozygous or compound heterozygous. These mutations have been observed before in patients in northern and southern Taiwan (Table 2). Three of the six mutations in our study, listed in Table 2 including the $\mathrm{C}$ to $\mathrm{T}$ transition at nucleotide 654 of IVS-2, the four-nucleotide deletion at codons $41 / 42$, and the A to T transversion at codon 17 , account for the great majority $(91.3 \%)$ of our detected $\beta$ thalassemia mutation alleles. The most common mutation, accounting for $42.1 \%$ of $\beta$-thalassemia mutation alleles in our study, was the $\mathrm{C}$ to $\mathrm{T}$ transition at nucleotide 654 of IVS-2, followed by the four-nucleotide deletion at codons $41 / 42(40 \%)$, A to $\mathrm{T}$ transversion at codon $17(9.2 \%)$, frameshift codons 71/72 (insertion of A) (3.9\%), A to G transversion at position -28 of promoter region $(2.6 \%)$, and frameshift codons $27 / 28$ (insertion of C) $(2.6 \%)$. Mutant alleles of the $\mathrm{G}$ to $\mathrm{T}$ transversion at nucleotide 1 of IVS-1 and IVS-1 $3^{\prime}$ end TAG $\rightarrow$ GAG, reported in other $\beta$-thalassemia mutation studies in northern and southern Taiwan, were not detected in this study (Table 2). Other

Table 1 Restriction enzymes that distinguish normal and all reported mutants in Taiwan

\begin{tabular}{|c|c|c|c|c|c|}
\hline \multirow[b]{2}{*}{ Mutation } & \multirow[b]{2}{*}{ Position } & \multirow[b]{2}{*}{ Primer sequence } & \multicolumn{2}{|c|}{ Restriction enzyme } & \multirow[b]{2}{*}{ Size of fragment } \\
\hline & & & Natural & Created & \\
\hline $\mathrm{A} \rightarrow \mathrm{G}$ & -28 & $\begin{array}{l}\text { 5'P: 5'-GCTTACCAAGCTGTGATTCC-3' } \\
\text { 3'P: 5'-GCAATAGATGGCTCTGCCCTGAATT-3' }\end{array}$ & - & Eco R I & $\begin{array}{l}292 \mathrm{bp}(\mathrm{N}) \\
267,25 \mathrm{bp}(\mathrm{M})\end{array}$ \\
\hline $\mathrm{AAG} \rightarrow \mathrm{TAG}$ & Codon 17 & $\begin{array}{l}\text { 5'P: 5'-CTGCCGTTACTGCCCTGTGGAGC-3' } \\
\text { 3'P: 5'-GGCAGAGAGAGTCAGTGCCTA-3' }\end{array}$ & Mae I & Alu I & $\begin{array}{l}170 \mathrm{bp}(\mathrm{N}) \\
147,23 \mathrm{bp}(\mathrm{M})\end{array}$ \\
\hline$+\mathrm{C}$ & Codon 27/28 & $\begin{array}{l}\text { 5'P: 5'-GGCAGGAGCCAGGCTGCG-3' } \\
\text { 3'P: the same as for-codon } 17\end{array}$ & Nla IV & - & $\begin{array}{l}298 \text { bp (N) } \\
184,115 \text { bp }(\mathrm{M})\end{array}$ \\
\hline - ТCTТ & Codon $41 / 42$ & $\begin{array}{l}\text { 5'P: 5'-CTGGTGGTCTACCCTTGGACCCAGAGGTC-3' } \\
\text { 3'P: 5'-TCATTCGTCTGTTTCCCATTCTAAAC-3' }\end{array}$ & - & $T a q \mathrm{I}$ & $\begin{array}{l}334 \text { bp (N) } \\
306,28 \mathrm{bp}(\mathrm{M})\end{array}$ \\
\hline $\mathrm{GAG} \rightarrow \mathrm{TAG}$ & Codon 43 & $\begin{array}{l}5^{\prime} \mathrm{P}: \text { the same as for codon } 41 / 42 \\
3^{\prime} \mathrm{P} \text { : the same as for codon } 41 / 42\end{array}$ & $\begin{array}{l}\text { Hinf I } \\
\text { (abolish) }\end{array}$ & - & $188,112,34 \mathrm{bp}(\mathrm{N})$ \\
\hline$+\mathrm{A}$ & Codon 71/72 & $\begin{array}{l}5^{\prime} \mathrm{P}: \text { the same as for codon } 41 / 42 \\
3^{\prime} \mathrm{P}: \text { the same as for codon } 41 / 42\end{array}$ & Mse I & Spe I (N) & $\begin{array}{l}216,25 \mathrm{bp}(\mathrm{N}) \\
242 \mathrm{bp}(\mathrm{M})\end{array}$ \\
\hline $\mathrm{C} \rightarrow \mathrm{T}$ & IVS-2nt 654 & $\begin{array}{l}\text { 5'P: 5'-GTGTATACATATTGACCAAATCAGGGTA-3' } \\
\text { 3'P: 5'-TGCAGAAATATTTATATGCAGAAATATTGC-TAGT-3' }\end{array}$ & - & Rsa I & $\begin{array}{l}232 \mathrm{bp}(\mathrm{N}) \\
198,34 \mathrm{bp}(\mathrm{M})\end{array}$ \\
\hline
\end{tabular}

$\mathrm{P}$, primer; $\mathrm{N}$, normal; $\mathrm{M}$, mutant 
mutations, such as those in promoter area: -29 and -30 , initiation codon mutation, IVS-1 nucleotide 5 mutation, codon 43 nonsense mutation, and codons 14/15 frameshift mutation, were not found in our study. As to mutation patterns in each individual, the incidence of compound heterozygotes of two differet mutations was higher than the incidence of homozygotes of a single mutation $(60 \%$ vs $40 \%$ ). The compound heterozygosity of the $\mathrm{C}$ to T substitution at nucleotide 654 of IVS-2 and codons 41/42 frameshift were the most common $(23.7 \%)$ pattern of mutation detected in patients with $\beta$-thalassemia major in central Taiwan (Table 3).

Clinical, hematological and $\mathrm{Hb}$ composition data

All 38 patients are transfusion-dependent and are currently being treated with deferoxamine mesylate (Desferal; Novartis, Switzerland). Table 3 lists the hematological data for all patients with specific nucleotide substitutions, with the mean levels of $\mathrm{HbA}_{2}, \mathrm{HbF}$, and $\mathrm{HbA}_{1}$. On comparing these data we found no significant differences among the individual genotypes. All patients needed early initial redcell transfusions before or around 1 year of age, except for one patient with homozygotes of a single mutation at nucleotide 654 of IVS-2, who did not receive an initial transfusion until 8.5 years of age. (Based on our three patients who also showed the $\alpha$-thalassemia trait, there were no apparent differences between them and the other $\beta$-thalassemia patients in terms of clinical manifestations.)

\section{Discussion}

In general, each population tends to have different or some specific mutation alleles in the $\beta$-globin gene, including some that are very common and others that are rare (Kazazian 1990; Bunn et al. 1986). In southern China, the distribution of mutations in the $\beta$-globin gene differs even within the three neighboring provinces of Guangdong, Guangxi, and Sichuan (Liu et al. 1989). This may be due to the large number of ethnic groups in this area.

Taiwanese have close ethnic ties to people in mainland China. The mutation spectrum of $\beta$-thalassemia among the mixture of populations in Taiwan was well established by Chang et al. (1992). In our study, the mutations of $\beta$ thalassemia in central Taiwan are similar to findings in previous reports of the mutations in northern and southern Taiwan (Table 2), but are unique compared to findings reported in southern China. Current data regarding specific mutations of $\beta$-globin genes in southern China can be traced

Table 2 Frequency of $\beta$-thalassemia major mutations in Taiwan

\begin{tabular}{|c|c|c|c|c|c|c|}
\hline \multirow[b]{2}{*}{ Mutation site } & \multicolumn{4}{|c|}{ This study (central Taiwan) } & \multirow{2}{*}{$\begin{array}{l}\text { Northern Taiwan } \\
\text { (Lin et al. 1991) } \\
n(\%)\end{array}$} & \multirow{2}{*}{$\begin{array}{l}\text { Southern Taiwan } \\
\text { (Chiou et al. 1993) } \\
n(\%)\end{array}$} \\
\hline & Min-Nan & Hakka & Mainlander & No $(\%)$ & & \\
\hline IVS-2 nt $654(\mathrm{C} \rightarrow \mathrm{T})$ & 21 & 9 & 2 & $32(42.1)$ & $34(45.9)$ & $38(46.3)$ \\
\hline Codons 41/42 (-TCTT) & 21 & 7 & 2 & $30(40)$ & $21(28.4)$ & $26(31.7)$ \\
\hline Codons $17(\mathrm{~A} \rightarrow \mathrm{T})$ & 6 & 0 & 1 & $7(9.2)$ & $8(10.8)$ & $5(6.1)$ \\
\hline Codons $71 / 72(+\mathrm{A})$ & 0 & 3 & 0 & $3(3.9)$ & $0(0)$ & $1(1.2)$ \\
\hline$-28(\mathrm{~A} \rightarrow \mathrm{G})$ & 2 & 0 & 0 & $2(2.6)$ & $8(10.8)$ & $7(8.5)$ \\
\hline Codons $27 / 28(+\mathrm{C})$ & 2 & 0 & 0 & $2(2.6)$ & $2(2.7)$ & $2(2.4)$ \\
\hline IVS-1 nt $1(\mathrm{G} \rightarrow \mathrm{T})$ & 0 & 0 & 0 & $0(0)$ & $0(0)$ & $1(1.2)$ \\
\hline IVS-1 $3^{\prime}$ end $($ TAG $\rightarrow$ GAG $)\left(\beta^{3^{\prime \prime}}\right.$ end $)$ & 0 & 0 & 0 & $0(0)$ & $0(0)$ & $1(1.2)$ \\
\hline$-29(\mathrm{~A} \rightarrow \mathrm{G}) \quad\left(\beta^{-29}\right)$ & 0 & 0 & 0 & $0(0)$ & $1(1.4)$ & $0(0)$ \\
\hline Total & 52 & 19 & 5 & $76(100)$ & $74(100)$ & $82(100)$ \\
\hline
\end{tabular}

Table 3 Genotypes and hematological data in 38 patients with $\beta$-thalassemia major in central Taiwan in the present study

\begin{tabular}{|c|c|c|c|c|c|c|}
\hline \multirow[b]{2}{*}{ Genotype } & \multirow{2}{*}{$\begin{array}{l}\text { Number of } \\
\text { patients }(\%)\end{array}$} & \multirow{2}{*}{$\begin{array}{l}\text { Age at first transfusion } \\
\text { (months) }\end{array}$} & \multicolumn{4}{|c|}{ Initial hematological data } \\
\hline & & & $\mathrm{Hb}(\mathrm{g} / \mathrm{dl})$ & $\mathrm{HbF}(\%)$ & $\mathrm{HbA} 2(\%)$ & HbA1 (\%) \\
\hline$\beta^{654} / \beta^{654^{* a}}$ & $8(21.6 \%)$ & $19.7^{\mathrm{b}} \pm 10.1$ & $6.1 \pm 1.1$ & $88.1 \pm 8.5$ & $2.6 \pm 2.2$ & $9.3 \pm 8.5$ \\
\hline$\beta^{41-42} / \beta^{41-42^{* a}}$ & $7(18.4 \%)$ & $6.5 \pm 3.8$ & $5.8 \pm 0.9$ & $95.5 \pm 8.6$ & $3.3 \pm 2.8$ & $1.2 \pm 1.0$ \\
\hline$\beta^{654} / \beta^{41-42}$ & $9(23.7 \%)$ & $7.3 \pm 3.5$ & $6.7 \pm 0.7$ & $90.6 \pm 7.1$ & $2.5 \pm 1.8$ & $6.9 \pm 6.7$ \\
\hline$\beta^{654} / \beta^{17}$ & $6(15.8 \%)$ & $6.7 \pm 2.1$ & $6.3 \pm 1.4$ & $94.3 \pm 5.8$ & $1.6 \pm 0.5$ & $4.1 \pm 3.8$ \\
\hline$\beta^{654} / \beta^{27-28}$ & $1(2.6 \%)$ & 13.0 & 7.4 & 89.5 & 1.4 & 9.1 \\
\hline$\beta^{41-42} / \beta^{17}$ & $1(2.6 \%)$ & 7 & 2.9 & 85.4 & 4.9 & 10.1 \\
\hline$\beta^{41-42} / \beta^{-28}$ & $2(5.3 \%)$ & $6.6 \pm 0.5$ & $5.5 \pm 0.6$ & $84.3 \pm 10.5$ & $4.5 \pm 2.5$ & $11.2 \pm 3.6$ \\
\hline$\beta^{41-42} / \beta^{71-72^{* a}}$ & $3(7.9 \%)$ & $9.8 \pm 3.1$ & $5.9 \pm 0.9$ & $77.2 \pm 7.3$ & $3.8 \pm 2.9$ & $19.1 \pm 6.5$ \\
\hline$\beta^{41-42} / \beta^{27-28}$ & $1(2.6 \%)$ & 14 & 4.4 & 96.7 & 2.44 & 0.8 \\
\hline
\end{tabular}

Values are means \pm SD, except where SD not shown

${ }^{* a}$ Each genotype includes one patient who also had the $\alpha$-thalassemia trait

${ }^{* b}$ One patient's first transfusion at age 8.5 years 
to patients from Guangdong province (Lam et al. 1990). Frameshift codons 41/42 ( -4 nucleotides deletion) were reported to be the most common mutation (Orkin et al. 1983; Kimura et al. 1983; Cheng et al. 1984; Kazazian et al. 1986; Chan et al. 1987, 1988; Antonarakis et al. 1988; Zhang et al. 1988; Huang et al. 1988). However, in our study, the allele frequency of the $\mathrm{C}$ to $\mathrm{T}$ substitution at nucleotide 654 of IVS-2 and frameshift codons 41/42 (-TCTT) are similar and are two of the most common mutations found in central Taiwan, followed by the codon $17(\mathrm{~A} \rightarrow \mathrm{T})$ mutation. The incidence of the nonsense codon 17 mutation in Guangxi and Sichuan provinces of mainland China is higher than the incidence of the IVS-2 nucleotide 654 and -28 mutations, but this characteristic is not shown in Guangdong province or in regions in northern and southern Taiwan, according to Liu et al. (1989) and our results. The A to $G$ substitution at position -29 in the promoter area is rare in Sichuan province and even rarer in Guangdong and Guangxi provinces and central Taiwan. These results may be linked to area and population variations. Our results are compatible with those of Chang et al. (1990) concerning the mutations of $\beta$-thalassemia minor in northern Taiwan and the $\mathrm{C}$ to $\mathrm{T}$ substitution at nucleotide 654 of IVS-2, which is still the most common type of mutation in $\beta$-thalassemia major. As to mutations within different populations of Taiwan, the spectra are similar in the Min-Nan and Hakka populations. Although many Hakka have roots in Guangdong province, their mutations may be closer to those in Min-Nan people than to those in people from in Guangdong. Our results are also similar to those concerning the mutations of $\beta$-thalassemia in northern and southern Taiwan (Lin et al. 1991; Chiou et al. 1993). Frameshift codons 27/28 (insertion of $\mathrm{C}$ ), which cause a premature termination of translation at the new codon 59, have been reported in two Hakka-Taiwanese and a patient from Guangdong province (Lin et al. 1991; Cai et al. 1991). Since this novel mutation was also detected in a Min-Nan patient in our study, it suggests that this mutation is not rare in the Chinese. This mutation decreases normal RNA splicing and has also been found in a Saudi-Arabian patient (Wong et al. 1989). Mutation of IVS-1 nucleotide 1 (G-T) is a common mutation in Indians, but is rare in Chinese, probably due to the migration of this mutant $\beta$-globin allele from India to China (Varamalla et al. 1991; Kazazian et al. 1986).

The patients in our study were subdivided according to whether they were either homozygotes or compound heterozygotes to characterize any differences between genotypes and clinical manifestations. Table 3 shows that all patients with homozygotes or compound heterozygotes of $\beta$-thalassemia mutation are likely to have Cooley's phenotype (WHO Working Group 1982) and needed early initial packed red cell transfusion before or around 1 year of age, except for one patient with homozygotes of nucleotide 654 of IVS-2, who did not receive an initial transfusion until 8.5 years of age. The reason for this long period is unclear and requires further investigation.

These characterization of mutations could be useful for genetic counseling, evaluation of clinical manifestations, and determining prenatal diagnosis programs for $\beta$ thalassemia patients in central Taiwan.

The data shown in Table 2 indicate the importance of identifying various mutations in a given population of Taiwan. The information is very useful for physicians when they are planning specific therapeutic approaches, for genetic counselors to educate young couples and families, and for scientists to understand the mutation's effect as expressed in a gene. It is equally important to establish prenatal diagnosis centers in order to reduce long-term health costs and channel resources to those areas where they can be used for the better management of affected individuals.

Acknowledgments We would like to thank Su-Ching Liu for her excellent technical support. We also wish to thank Yu-Huei Liang for her assistance in preparing the manuscript and Prof. Tsai-Chung Li for statistical analysis.

\section{References}

Antonarakis SE, Kang J, Lam VMS, Tam Jwo, Li AMC (1988) Molecular characterization of $\beta$-thalassemia intermedia in South China. Br J Haematol 70: 357-361

Bunn HF, Forget BG (1986) Hemoglobin: Molecular, genetic and clinical aspects. W.B. Saunders, Philadelphia

Cai SP, Chui DHK, Ng J, Poon AO, Freedman MH, Olivieri NF (1991) A new frameshift $\beta^{\circ}$-thalassemia mutation (codons 27-28 + C) found in a Chinese family. Am J Hematol 37: 6-8

Chan V, Chan TK, Chehab FF, Todd D (1987) Distribution of $\beta$ thalassemia mutations in South China and their association with haplotypes. Am J Hum Genet 41: 678-685

Chan V, Chan TK, Kan YW, Todd D (1988) A novel $\beta$-thalassemia frameshift mutation (codon 14/15) detectable by visualization of abnormal restriction fragment in amplified genomic DNA. Blood 72: 1420-1423

Chang JG, Chen PH, Chiou SS, Lee LS, Perng LI, Liu TC (1992) Rapid diagnosis of $\beta$-thalassemia mutations in Chinese by naturally and amplified created restriction sites. Blood 80: 2092-2096

Chang JG, Liu TC, Lin CP, Chen PH, Lee LS (1990) Molecular basis of $\beta$-thalassemia minor in Taiwan (abstract). Blood 76: 57

Cheng T, Orkin SH, Antonarakis SE, Potter MJ, Sexton JP, Giardina PJV, Li A, Kazazian HH Jr (1984) $\beta$-Thalassemia in Chinese: use of in vitro RNA analysis and oligonucleotide hybridization in systemic characterization of molecular defects. Proc Nat'l Acad Sci, USA 81: 2821-2825

Chiou SS, Chang TT, Chen PH, Lee LS, Chen TS, Chang JG (1993) Molecular basis and hematological characterization of $\beta$-thalassemia major in Taiwan, with a mutation of IVS-1 3' end TAG-GAG in a Chinese patient. Br J Haematol 83: 112-117

Huang S, Waber PG, Dowling CE, Wong C, Antonarakis SE, Cai RL, Wang MQ, Lo WH, Kazazian HH Jr (1988) $\beta$-Thalassemia in China: A systemic molecular characterization of $\beta$-thalassemia mutations. Hemoglobin 12: 621-628

Kazazian HH Jr (1990) The thalassemia syndromes: Molecular basis and prenatal diagnosis in 1990. Semin Haematol 27: 209-228

Kazazian HH Jr, Dowling CE, Waber PG, Hung S, Lo WHY (1986) The spectrum of $\beta$-thalassemia genes in China and Southeast Asia. Blood 68: 964-966

Kimura A, Matsunaga E, Takihara Y, Nakamura T, Takagi Y, Lin ST, Lee MT (1983) Structural analysis of a $\beta$-thalassemia gene found in Taiwan. J Biol Chem 258: 2748-2749

Ko TM, Hsu PM, Chen CJ, Hsieh FT, Hsieh CY, Lee TY (1989) Incidence study of heterozygous $\beta$-thalassemia in northern Taiwan. J Formosan Med Assoc 88: 678-681

Lam VMS, Xie SS, Tam Jwo, Woo YK, Gu YL (1990) A new single nucleotide change at the initiation codon (ATG-AGG) identified in 
amplified genomic DNA in a Chinese $\beta$-thalassemia patient. Blood 75: 1207-1208

Lin LI, Lin KS, Cheng TY (1992) A novel-32 (C-A) mutation identified in amplified genomic DNA of Chinese $\beta$-thalassemia patients. Am J Hum Genet 50: 237-238

Lin LI, Lin KS, Lin KH, Chang HC (1991) The spectrum of $\beta$ thalassemia mutations in Taiwan. Am J Hum Genet 48: 809-812

Liu JZ, Gao QS, Jiang Z, Liang CC, Yang KG, Wu GY, Long GF, Li Q, Zang J, Deng B (1989) Studies of $\beta$-thalassemia mutations in families living in three provinces in southern China. Hemoglobin 13: $585-595$

Orkin SH, Sexton JP, Cheng TC, Goff SC, Giardina PJV, Kazazian HH $\mathrm{Jr}$ (1983) TATA box transcription mutation in $\beta$-thalassemia. Nuc Acids Res 11: 4721-4734

Weatherall DJ, Clegg JB (1981) Thalassemia syndromes, 3rd ed. Blackwell Scientific Publications, Oxford

Varamalla NY, Old JM, Venkatesan SR, Weatherall DJ (1991) The spectrum of $\beta$-thalassemia mutations on the Indian subconti- nent: the basis for prenatal diagnosis. Brit J Haematol 78: 242247

WHO Working Group (1982) Hereditary anemias: Genetic basis, clinical features, diagnosis, and treatment. Bull WHO 60: 643-660

Wong C, Dowling CE, Saiki RK, Higuchi RG, Erlich HA, Kazazian $\mathrm{HH} \mathrm{Jr}$ (1987) Characterization of $\beta$-thalassemia mutations using direct genomic sequencing of amplified single copy DNA. Nature 330: $384-386$

Wong C, Antonarakis SE, Goff SC, Orkin SH, Forget BG, Nathan DG, Giardian PJV, Kazazian HH Jr (1989) $\beta$-Thalassemia due to two novel nucleotide substitutions in consensus acceptor splice sequences of the $\beta$-globin gene. Blood 73: 914-918

Xu YH, Zhang ML, Ren JR, Huang SZ, Zeng YT (1990) A novel Chinese $\beta$-thalassemia mutation - 4bp (AAAC) deletion at position +40 to +43 from the cap site (abstract). Blood 76: 81

Zhang JZ, Cai SP, He X, Lin HX, Lin HJ, Huang ZG, Chehab FF, Kan YW (1988) Molecular basis of $\beta$-thalassemia in south China. Strategy for DNA analysis. Hum Genet 78: 37-40 